\title{
AS SESMARIAS NAS ORDENAÇÕES DO REINO
}

\author{
THE "SESMARIAS” IN THE “ORDENAÇÕES DO REINO” ACTS
}

Tabir Dal Poggetto Oliveira Sueyoshi ${ }^{1}$

\begin{abstract}
Resumo:
O texto aborda a disciplina das sesmarias nas três Ordenações do Reino: Afonsinas, Manuelinas e Filipinas. As Ordenações Afonsinas se destacam, no presente trabalho, por conterem mais disposições sobre as sesmarias que as Ordenações posteriores, bem como o modo enfático da distribuição de terras condicionadas à produção de alimento.

Palavras-chave: Ordenações do Reino Lei de Sesmarias de D. Fernando. Agricultura. Alimentação.
\end{abstract}

\begin{abstract}
The text addresses the discipline of the "sesmarias" in the three "Ordenações do Reino" (Kingdom Ordinances of Portugal): Afonsines, Manuelines and Filipines. The Afonsine Ordinations shines, in the present paper, for contains more dispositions about the "sesmarias" than the later Ordinations, and the emphatic way of land distribution conditioned to the food production.
\end{abstract}

Keywords: Kingdom Ordinations. Law of "sesmarias" of D. Fernando. Agriculture. Food.

1. Os antecedentes das sesmarias.

A Lei de Sesmarias foi promulgada no Reinado de D. Fernando e posteriormente incorporada às Ordenações de D. Afonso V. O Autor Gama Barros, em História da Administração Pública em Portugal ${ }^{2}$ afirma que a Lei de Sesmarias foi promulgada em cortes, porém não precisando o local e a data de sua promulgação. Afirma ainda ser posterior a 28 de maio de 1375, data da publicação da lei em Santarém.

Atribuiu-se o nome de sesmarias devido ao costume antigo de dividir as terras em seis partes. ${ }^{3}$ Contudo, as três Ordenações do Reino não mencionam este modo de divisão de terras em seis partes. De outra parte, nos comentários às Ordenações Filipinas,

\footnotetext{
1 Mestrando do curso de Pós-Graduação da Faculdade de Direito da Universidade de São Paulo e bolsista da CAPES. Trabalho apresentado sob a forma de seminário na disciplina História do Direito do curso de Pósgraduação da Faculdade de Direito da Universidade de São Paulo, sob a regência dos professores doutores Luiz Carlos Azevedo e Ignacio Maria Poveda Velasco, em maio de 2006.

2 BARROS, Henrique de Gama. História da Administração Pública em Portugal nos séculos XII a XV. Direção de Torquato de Souza Soares 2. ed. Lisboa: Sá da Costa, 1945. v. 8, p. 317.

3 CAETANO, Marcelo. História do Direito Português (séculos XII a XVI) seguida de subsídios para a História das Fontes do Direito em Portugal no século XVI. Textos introdutórios e notas de Nuno Espinosa Gomes da Silva. Lisboa: Editora Verbo, 2000. p. 280.
} 
Cândido Mendes de Almeida ${ }^{4}$ transcreve o significado do vocábulo sesmaria do Elucidário de Fr. Joaquim Santa Rosa do Viterbo, concluindo que "sesma" quer dizer a sexta parte de qualquer coisa, neste caso a pensão de sexto. Cremos que este significado corresponda melhor à realidade da época, já que a enfiteuse era o contrato mais habitual.

Há três fatores que influenciaram a promulgação da Lei de Sesmarias no Reinado de D. Fernando: a peste negra, a guerra e o êxodo rural. Todos estes fatores têm em comum a diminuição da população rural em Portugal, sobretudo numa época em que as técnicas de plantio ainda eram bem rudimentares.

O problema agrícola português é anterior ao Reinado de D. Fernando. Alexandre Herculano, ${ }^{5}$ com base nas crônicas "Turonense" e "Conimbricense", aborda a questão da escassez de gêneros agrícolas no final do século XII e princípios do século XIII. Relata-nos este Autor que as freqüentes ondas de fome, como também as sucessivas guerras dizimavam a população rural. Em períodos de relativa paz, inclusive, a fome devastava tudo, tanto homens como animais. Além disso, a falta de técnicas, as intempéries e a difícil comunicação não possibilitavam a produção e a distribuição de gêneros agrícolas, de modo a atender a necessidade dos súditos em diversos lugares do Reino.

Nesse contexto de fome e doenças, D. Fernando em cortes promulga a Lei de Sesmarias.

\section{As sesmarias nas Ordenações Afonsinas}

As Ordenações de D. Afonso V, promulgadas em 1446, são uma compilação de leis e de costumes até então vigentes; resultado de um trabalho iniciado no Reinado de D. João I. Este Rei havia mandado João Mendes compilar a legislação promulgada até então. No Reinado de D. Duarte esta tarefa foi prosseguida pelo Doutor Rui Fernandes. O trabalho foi terminado no Reinado D. Afonso V, em 28 de julho de 1446, pelo Doutor Rui Fernandes, revisto ulteriormente por uma comissão composta deste jurista e outros três: Doutor Lopo Vasques, Luís Martins e Fernão Rodrigues. ${ }^{6}$

\footnotetext{
4 ORDENAÇÕES Filipinas. Lisboa: Fundação Calouste Gulbenkian, 1985, reprodução fac-símile da edição brasileira de Cândido Mendes de Almeida, 14. ed. Rio de Janeiro: Tipografia do Instituto Filomático, 1870, edição segundo a primeira de 1603 e a nona de 1824, p. 822, nota de rodapé n. 3 .

5 HERCULANO, Alexandre. História de Portugal, desde o começo da monarquia até o fim do Reinado de D. Afonso III. Lisboa: Livraria Bertrand, 1980. t. II, p. 126-127, notas críticas de José Matoso, verificação do texto pro Ayala Monteiro.

6 COSTA, Mário Júlio de Almeida. História do Direito Português. 3. ed. 2. reimp. Coimbra: Almedina, 2000. p. 274.
} 
As sesmarias estão disciplinadas no Livro IV, Título LXXXI, das Ordenações Afonsinas. A matéria é dividida em 38 partes. Desta divisão, a Lei de Sesmarias de D. Fernando é reproduzida até o número 18 , de acordo com a confrontação que realizamos entre o texto das Ordenações Afonsinas e o texto transcrito por Virgínia Rau em seu livro Sesmarias Medievais Portuguesas?. Nos números 18 e 19 estão as "ordenações sobre o gado". Do número 20 adiante reproduzem disposições sobre a concessão de sesmarias na "Villa d'Estremoz", sendo de D. João I as constantes nos números 20 a 23, de 1427. Do número 23 até o número 34 as resoluções de dúvidas apresentadas a D. Duarte, que o concelho recebeu traslado, em $1436 .{ }^{8}$ Os quatros últimos números há disposições que reiteram as anteriores de todo título.

Os motivos da Lei de Sesmaria estão expostos no número 1, como segue:

EL REY Dom Fernando, de louvada e esclarecida memoria, em seu tempo fez Ley em esta forma, que se segue.

1. Dom Fernando pela graça de DEOS Rei de Portugal, e do Algarve. Consirando como por todas as partes de nossos Regnos há desfalicimento de mantimento de trigo, e de cevada, de que antre todalas Terras, e Províncias do Mundo soyam seer muy abastadas, eestas cousas som postas em tamanha carestia, que aquelles, que ham de manteer fazenda ou estado de qualquer graao de honra, nom podem chegar a aver essas cousas, sem mui grande desbarato do que ham; e esguardando como antre todalas razooẽs, per que este desfalicimento e carestia vem, mais certa e especial he per mingua das lavras, que os homeẽs leixam, e se partem dellas, entendendo em outras obras, e em outros mesteres, que nom som tam proveitosos pera o bem commum; e as terras e herdades, que soyam a seer lavradas e semeadas, e que som convinhavees pera dar pam, e outros fruitos, per que se os Povoos ham de manteer, som desamparadas, e deitadas em Ressios, sem prol, e com grande dapno do Povo. ${ }^{9}$

O motivo da Lei de Sesmarias acima transcrito demonstra a preocupação em tornar as terras produtivas, principalmente da matéria-prima do pão: trigo e cevada. No final do número em comento, encontramos de modo explícito a referência ao pão, alimento básico de diversos povos.

\footnotetext{
7 RAU, Virgínia. Sesmarias Medievais Portuguesas. Lisboa: Editorial Presença, 1982. p. 267-275, prólogo e adenda documental por José Manuel Garcia.

8 BARROS, Henrique de Gama. op. cit., p. 325.

9 ORDENAÇÕES Afonsinas. In: Collecção da Legislação Antiga e Moderna do Reino de Portugal - Parte I - da Legislação Antiga - por resolução de S. Magestade de 02 de setembro de 1786. Coimbra: Real Imprensa da Universidade de Coimbra, 1797; reprodução "fac-simile", Lisboa: Fundação Calouste Gulbenkian, 1984, p. 281, negritos nossos.
} 
A "abastança" presente nas "Terras e Províncias do Mundo", no que tange a Europa Ocidental, não era tão expressiva se compararmos com Portugal, como acima dissemos. Não pensamos que o cenário agrícola europeu tenha mudado de maneira radical entre os séculos XII, XIII e XIV, em virtude do avanço das técnicas agrícolas e fatores climáticos.

A lavoura não era, como ainda não é, uma atividade de resultado certo. Todo o trabalho despendido ao preparar a terra, semear e aguardar a colheita é demorado, dependendo de condições climáticas e epidêmicas para uma boa colheita. Um trabalho tão-árduo e imprevisível impelia o camponês a tentar novos modos de viver em "outros mesteres" mais confortáveis e de resultado mais certo.

No número 2 vemos o modo como é ordenado o "remédio", "verbis":

$2 \ldots$

... Estabelecemos, hordenamos, e mandamos, que todos os que ham herdades suas proprias, ou teverem emprazadas, ou afforadas, ou per qualquer outra guisa ou titulo, per que ajam direito em essas herdades, sejam costrangidos pera as lavrar, e semear; e se o Senhorio das ditas herdades nom poder per sy lavrar todalas ditas herdades que ouver, por serem muitas, ou em desvairadas Comarcas, ou elle for embargado por alguma lidima razom, por que as nom possa per sy lavrar todas, lavre parte dellas per sy, e per hu elle quiser, e lhe mais aprouver, e quanta lavrar poder sem grande seu dapno, e com meor seu encarrego, a bem vistas e determinaçom daquelles, a que desto for dado poder; e as mais faça lavrar per outrem, ou as dê a lavrador, que as lavre e semmee por sua parte, ou pensom certa, ou a foro, assy como se melhor poder fazer; de guisa que as herdades, que som pera dar pam, sejam todas lavradas, e semeadas compridamente, como for mester, de trigo, ou cevada, ou de milho, pera qual for, e que mais fruito e melhor possa dar em seus tempos e sazooẽs convinhavees. ${ }^{10}$

A terra deveria ser cultivada não importando o modo. O plantio deveria ser direto, com dispêndio do "Senhorio", ou de outrem a seu mando ou por ele contratado. Podemos pensar que se trata do contrato agrário de arrendamento ou constituição de enfiteuse ao dizer: "ou pensom certa, ou a foro, assy como se melhor poder fazer”. Nãoobstante, não temos elementos suficientes para afirmarmos que se tratava de arrendamento, uma vez que não consta na lei um prazo determinado para o uso da terra. Parece-nos não ser arrendamento, mas constituição de enfiteuse, corroborando nesse sentido a nota

\footnotetext{
${ }^{10}$ Ordenações Afonsinas. op.cit. p. 282-283, negritos nossos.
} 
explicativa do saudoso professor Doutor Olavo Acyr de Lima Rocha em artigo sobre os contratos agrários nas Ordenações Filipinas:

Como se sabe, pelo contrato de aforamento ou enfiteuse, o proprietário de um imóvel, por ato entre vivos ou de última vontade, atribui a outrem o domínio útil de um imóvel, reservando o domínio direto para si, pagando a pessoa que adquire o domínio útil, uma pensão ou foro anual certo e invariável. É também chamado emprazamento, foro $e$ prazo. ... A enfiteuse ou aforamento de imóveis rurais pode ser disciplinado sem qualquer exagero pelo Direito Agrário. Basta lembrar seu grande prestígio no período medieval, para permitir a produção de glebas rurais. ${ }^{11}$

O verbo constranger está presente em quase toda Lei de Sesmaria, o que demonstra a preocupação do legislador com o problema de escassez de alimentos. O verbo constranger no texto da Lei das Sesmarias tem o sentido de compulsoriedade, a fim de aumentar a produção agrícola.

Encontra-se disposto no número 3 um estímulo para aquisição de bois para o arado. Quem fosse criador de gado bovino poderia ser "costrangido" a vender os seus bois por preços determinados pelos juízes dos lugares ou "veedores" para o lavrador que os pretendesse comprar.

A Justiça do Lugar "ou aquelles, a que para esto for dado poder" tinham a tarefa de distribuir a terra para quem quisesse "por pensom, ou parte certa" para o bemcomum. Os encarregados de distribuir as terras incultas ainda não são, até esse trecho, denominados sesmeiros.

Aqueles que possuíssem menos de quinhentas libras não estavam isentos do cumprimento da lei. Deveriam lavrar as suas herdades ou procurar outras pessoas que a tivessem para "obra de proveitoso serviço" (Ord. Afonsinas, Liv. IV, Título LXXXI, n. 6). Mais uma vez o legislador reitera a importância de tornar a terra agricultável e produtiva.

Há exceções à regra da compulsoriedade. Aqueles que se diziam mancebos dos fidalgos ou " $d$ ' $E l$ - Rey" deveriam provar tal estado mediante uma certidão. Se não tivessem certidão ou se o seu estado não fosse de conhecimento notório, seriam submetidos à averiguação pelas Justiças dos lugares. Se no caso fosse verificado que não eram mancebos ou serviçais dos fidalgos, seriam forçados a trabalhar na lavoura, sob pena de

${ }_{11}$ ROCHA, Olavo Acyr de Lima. As Ordenações Filipinas e o Direito Agrário. Revista da Faculdade de Direito da Universidade de São Paulo, São Paulo, v. 95, p. 33-55, jan./dez. 2000; nota de rodapé n. 10, negritos nossos. Edição em homenagem aos 500 anos do Descobrimento do Brasil. 
açoites na recusa (Ord. Afonsinas, Liv. IV, Título LXXXI, n. 8). As pessoas que habitavam junto dos mosteiros e conventos, sem serem religiosos professos, da mesma maneira que os mancebos, deveriam ser lavradores, incidindo a pena de açoite com agravantes se houvesse reincidência: açoite "em pregom" com degredo do Reino (Ord. Afonsinas, Liv. IV, Título LXXXI, n.10).

Substancia as punições determinadas na Lei de Sesmarias a notícia que nos conta Virgínia Rau, apoiada em documento de representação dos concelhos a D. Fernando nas cortes de Lisboa de 1371, "verbis":

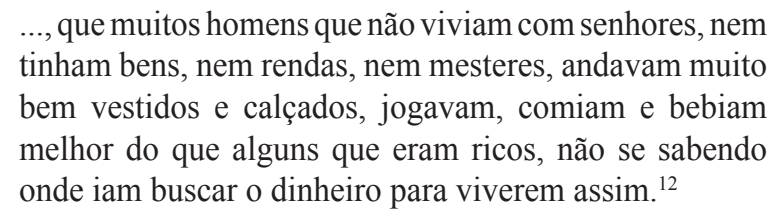

Esta notícia demonstra a razão da punição severa determinada na Lei de Sesmaria. Nesse contexto no qual a vadiagem crescia aos olhos de todos, bem como a escassez de alimentos aumentava na mesma proporção, ou em maiores proporções, não seria diverso o meio utilizado para suprir a insuficiência de gêneros alimentícios.

No entanto, os mendigos, que estavam nessa situação por não estarem aptos ao trabalho, deveriam exibir um alvará concedido pela Justiça. O modo como é referido o mendigo enfatiza o seu estado de saúde, isto é, é lícito mendigar apenas aos que não têm vitalidade. Tratava-se de uma medida de misericórdia para quem não tivesse outra forma digna de sobreviver, como segue:

11. E AQUELLES, que forem achados tam fracos, e tam velhos, ou doentes per tal guisa, que nom possam fazer nenhuma obra de serviço, ou alguuns envergonhados, que já fossem honrados, e caissem em mingua, e proveza, em guisa que nom podem escusar o pedir das esmolas, e nom som pera servirem outrem, dem-lhes as Justiças Alvaraees, per que possam pedir essas esmolas seguramente. E qualquer homem, ou molher, que acharem andar pedindo sem recado, ou sem Alvará da Justiça, dem-lhe a pena suso dita. ${ }^{13}$

No número seguinte, a Lei de Sesmaria passa a tratar dos dois magistrados incumbidos de obrigar os responsáveis das herdades, sob qualquer título, a lavrar e semear a terra. São designados aqui como "homens bons". Ademais, os dois magistrados deveriam dirimir as desavenças entre os "senhores das herdades" e os lavradores, fixando o valor

\footnotetext{
${ }^{12}$ RAU, Virgínia. Sesmarias medievais portuguesas. Lisboa: Editorial Presença, 1982. p. 84.

13 Ordenações Afonsinas. op. cit., p. 289, negritos nossos.
} 
devido pelos lavradores. Se não houvesse acordo entre os dois magistrados sobre a fixação do valor devido, competia ao juiz do lugar designar um terceiro para intervir na questão. A decisão do terceiro era definitiva. Se os senhorios não concordassem com a decisão, suas herdades seriam confiscadas em prol da localidade (Ord. Afonsinas, Liv. IV, Título LXXXI, números 13 e 14).

A Lei de Sesmaria é omissa quanto à escolha dos "homens bons". Gama Barros, embasado em dois documentos da Chancellaria de D. Fernando, por indução, diz que a escolha dos sesmeiros era por meio de eleição do concelho e posterior confirmação régia. ${ }^{14}$

Da leitura do início do parágrafo, sob o número 13, temos outro elemento que nos induz ao contrato agrário de arrendamento ou constituição de enfiteuse, como forma de aproveitamento da terra, "verbis":

13. E PORQUE os Senhores das herdades as nom querem dar a outros, que as lavrem, senom por grandes peensooẽs, ou por muy grandes rendas, $\ldots{ }^{15}$

Ainda que se se tratasse de arrendamento ou de constituição de enfiteuse, era compulsório, posto que os senhorios eram compelidos a tornar a terra agricultável, por si ou por outrem, sob pena de confisco.

A obrigação de lavrar e semear, como dissemos anteriormente, era geral. No fito de aplicar a Lei de Sesmaria, os "homens bons" deveriam fiscalizar todos os súditos, igualmente os senhorios, que não estavam imunes de cumpri-la (Ord. Afonsinas, Liv. IV, Título LXXXI, n. 15).

O número 16 refere-se ao ganha-dinheiro. Em consulta ao Dicionário Eletrônico Houaiss da Língua Portuguesa, ${ }^{16}$ o vocábulo ganha-dinheiro tem o significado próximo de diarista; jornaleiro, ou seja, quem trabalha por remuneração diária e sem vínculo permanente. A Lei de Sesmaria atenua neste ponto o seu rigor ao dizer que onde havia tais profissionais, que os deixasse em número necessário. Presume-se que os ganhadinheiros fossem profissionais de atividades de mercancia ou artesãos, donde advém a sua indispensabilidade.

Abaixo segue o número 17 que abriga as punições mais severas, encerrando a parte da Lei de Sesmarias promulgadas ao tempo de D. Fernando, "verbis":

\footnotetext{
14 BARROS, Henrique de Gama. História da administração pública em Portugal nos séculos XII a XV. Direção de torquato de Souza Soares. 2. ed. Lisboa: Sá Costa, 1945. v. 3, p. 324.

15 Ordenações Afonsinas. op. cit., p. 290.

${ }^{16}$ HOUAISS, Antônio. Dicionário Eletrônico Houaiss da Língua Portuguesa. Rio de Janeiro: Editora Objetiva Ltda., 2002. vocábulo ganha-dinheiro.
} 
17. E PARA esto, que assy hordenamos e mandamos fazer por serviço de DEOS e prol dos nossos Regnos, nom seer torvado, nem embargado per nenhuũ, estabelecemos e mandamos que qualquer, de qualquer estado e condiçom que seja, que per seu poderio, sem razom direta, defender ou embargar per qualquer maneira fora de Juízo alguũ daquelles, que mandamos per esta Hordenaçom costranger, ou que forem costrangidos per aquelles, a que pera esto for dado poder ou officio, pera nom servirem, ou nom obrarem em aquello, que lhes for mandado, que paguem a nós, se for fidalgo, quinhentas libras cada vez que o fezer, ou temptar de o fazer; e sejam logo per esse meesmo feito, sem outra sentença de Juízo, desterrados do lugar, hu morarem; e saia-se logo d'hy sem outro mandado donde quer que nós estevermos a seis legoas: e se fidalgo nom for, que pague trezentas libras, e aja a dita pena do dito degredo; e sejam logo penhorados, e costrangidos, e vendidos seus beẽs pela dita conthia, pela guisa que per nós he mandado, que se vendam pelas outras nossas dividas. $E$ as Justiças dos lugares, e outro sy aquelles, a que for dado poder pera esto comprir, que a cá per nós he ordenado, o façam saber ao nosso Sacador, e ao nosso Almuxarife, e Escripvam dos nossos direitos, pera mandarem costranger polas ditas penas; $e$ se o nom fezerem, ou em ello forem negrigentes, que esses Juizes, e Vereadores as paguem a nós em dobro. ${ }^{17}$

As penas são deveras pesadas ao impor o pagamento de multa, confisco de bens, desterro e o degredo. Elas enfatizam o intento do legislador em metamorfosear a conjuntura agrícola de então. A rigidez da lei é realçada ao punir a tentativa. Quanto à revisão da decisão de desterro, do trecho em exame podemos concluir que não havia possibilidade de recorrer da decisão ao Rei ou outro julgador. Por seu turno, os encarregados de recolher os bens confiscados estavam sujeitos a punições; uma maneira de se evitar a corrupção.

A distância de seis léguas, supomos, é devida ao fato de que o Rei naquele tempo andava pelo território de seu reino a comandar as suas milícias. Se o Rei estivesse próximo da localidade, talvez o próprio Rei, se fosse necessário, iria executar a lei. Cremos ser mais uma maneira de reforçar o vigor da punição para que a lei fosse bem observada.

A Lei de Sesmarias, de D. Fernando, termina no trecho retrotranscrito. A partir daqui, nos números 18 e 19, encontramos a Ordenação dos Gados do referido monarca. O teor da Lei de Sesmaria prioriza o plantio em detrimento da criação de

17 Ordenações Afonsinas, op. cit., p. 293, negritos nossos. 
gados. Não é surpreendente o modo enfático da Lei de Sesmaria em prol da plantação. No Alentejo, região de terra dura e rebelde, bem como em outros cantos do Reino, os camponeses preferiam criar animais ao invés de plantar por não haver mão-de-obra suficiente provocada pelo êxodo rural. ${ }^{18}$ Segundo o número 18 , o pastoreio é permitido sob condição do cultivo da terra. Esta regra, nos valendo da pesquisa de doutoramento de Virgínia Rau, pode ter sua origem em D. Pedro I, que, seguindo o entendimento de seus antecessores, ordenou que se pudesse haver gados suficientes apenas para o arado, proibindo o número que excedesse dezesseis cabeças de gado, inclusive proibir a cessão de terras incultas para pasto. ${ }^{19}$

A punição, de acordo com o número 19, para quem não cumprisse a Ordenação, depois de três meses de sua publicação, era o confisco para o comum do lugar e a terça parte para quem acusasse e mostrasse os gados. Esta disposição reforça a idéia de promover a agricultura em prejuízo da pecuária. Por isso, não é cabível designar a Lei de Sesmarias de agrária, na concepção jusagrarista hodierna, posto que o conceito de agrário não exclui a atividade pecuária.

Os números 20, 21 e 22 contêm a confirmação de Álvaro Gonçalves, da Vila d’Estremoz, na função de sesmeiro. Encontramos uma inovação no número 22. Estabelecese um procedimento antes de dar os bens em sesmaria. O sesmeiro era obrigado a efetuar o pregão e tornar os editos públicos no prazo de quatro a cinco dias. Os senhorios das herdades em questão deveriam cultivar a terra no prazo de um ano de qualquer modo. Passado este prazo, o sesmeiro estava autorizado a dar a herdade a quem estivesse disposto a cultivá-la. No entanto, observamos que a Lei de Sesmaria foi omissa neste ponto ao não-disciplinar o modo de distribuição de terras, deixando inteiramente ao arbítrio do sesmeiro, contrariando o disposto no número 13. Por isso, a ordenação de D. João I ao sesmeiro Álvaro Gonçalves, ao ser incorporada nas Ordenações Afonsinas, passaram a ser norma de observância geral.

Dos números 26 ao 35 do título em comento, estão as respostas de questionamentos propostos por Álvaro Gonçalves ao Rei D. Duarte. A competência para o julgamento de litígios sobre distribuição de sesmarias era do juiz ordinário. Vale lembrar que o juiz ordinário ou do lugar eram eleitos e aplicavam o Direito costumeiro, ao contrário do juiz de fora, que era nomeado pelo Rei e tinha formação universitária; era

\footnotetext{
18 RAU, Virgínia. op. cit., p. 84.

19 Id. Ibid., p. 85-86.
} 
o chamado letrado. ${ }^{20}$ Álvaro Gonçalves tinha consultado D. Duarte nesse ponto, porque existiam muitos lugares em Estremoz que se encontravam abandonados.

No fito de cumprir bem a sua função, cremos que a carta testemunhável de D. Duarte, datada de 11 de maio de 1476, incorporada às Ordenações Afonsinas, mostra que as dúvidas do sesmeiro Álvaro Gonçalo eram pertinentes. Prosseguindo o nosso comento, no número 26 consta uma ordem que inclui os bens da Igreja, antes não-mencionados na Lei de Sesmarias. D. Duarte responde ao sesmeiro d'Estremoz que obriguem os clérigos responsáveis pelos bens da Igreja de torná-los produtivos. No restante das respostas de D. Duarte ao sesmeiro d'Estremoz, os tutores dos menores deveriam tomar providências no sentido de tornar os bens de seus tutelados produtivos, sob pena de confisco dos bens dos tutores. Os bens de foragidos da Justiça, os "hominiziados", nos termos das Ordenações Afonsinas, deveriam ficar sob a custódia de um curador. Para os fidalgos, o sesmeiro deveria fixar um prazo para que estes pudessem tornar a terra produtiva, exceto as terras de reguengo, uma vez que estas cabiam ao almoxarife fiscalizar e cobrar os tributos.

Abaixo segue o número 31, Título LXXXI, do Livro IV, das Ordenações Afonsinas, onde podemos observar a preocupação do sesmeiro d'Estremoz em cumprir a sua função:

31. OUTRO SY faço saber aa vossa mercee, que em esta Villa, e termo della ha tres cousas, per que esta Villa, e moradores della som muito honrados, e as gentes ham sua vida, e mantimento: a primeira he, que há hy muitos olivaaes, os quaees, se aproveitados fossem como deviañ, averia hy muito azeite, e ora a maior parte delles som perdidos per mingua d'adubio, porque som em tam grande mato, que quando os fogos veem, nom os podem emparar nem defender, e o fogo os queima, e estrue em tanto, que já hy nom há a meetade dos que em outro tempo soya d'aver, o que nom seria, se aproveitados fossem: e alguuns, por lhe nom serem dados de sesmarias, e pera embargarem de lhos nom tomarem escavam, cortam algumas oliveiras, e nom querem roçar os matos, nem lavrar as terras, e assy jazem em perdiçom, e elles recebem dapno, e alguuns vizinhos por elles, que o seu adubam: seja vossa mercee tornar a esto, e declarardes a maneira que se tenha.

QUANTO a este Capitulo, respondemos que requeiram aos donos delles, que os corregam, se nom que os darom de sesmaria a quem nos correga. ${ }^{21}$

\footnotetext{
${ }^{20}$ Ordenações Filipinas. op. cit., p. 134, nota de rodapé n. 2.

${ }^{21}$ Ordenações Afonsinas. op. cit., p. 301, negritos nossos.
} 
Encontramos explicitamente, no excerto acima reproduzido, as técnicas de cultivo da terra utilizadas na época, aplicadas ainda hoje em alguns lugares. O emprego da queimada para derrubar o mato é preferido ao do roçar, mais trabalhoso, demandando o número maior de homens. Porventura o uso do fogo fosse necessário, porque não havia homens suficientes ou dispostos a "pegar no cabo da enxada".

D. Duarte autorizou a exploração da terra segundo o sistema de afolhamento, que consistia em dividir a terra em parcelas, de modo que algumas são cultivadas, enquanto outras ficam em repouso ${ }^{22}$ (Ord. Afonsinas, livro IV, título LXXXI, número 32).

Como vimos retro, o sesmeiro Álvaro Gonçalo nos parece que procurou cumprir bem o seu mister. No entanto, não eram todos os sesmeiros que eram zelosos na função de distribuir as terras incultas e de fiscalizar o seu uso. Gama Barros, ${ }^{23}$ lastreado em farta documentação, exemplifica alguns casos da aplicação da lei. Em Sesimbra, em 1430, o povo se queixava da forma como eram distribuídas as terras pelo sesmeiro, que estava vinculado à Ordem de São Tiago. O sesmeiro não realizava previamente uma audiência ou citava os possuidores de terras a serem dadas em sesmarias. Esse abuso causava muito contratempo em litígios e viagens. Em resposta, o Infante D. Pedro declarou que as concessões fossem nulas. A falta de citação antes de dar a terra em sesmaria é vista em outro caso da vila de Montemor-o-Novo, segundo a Carta Régia datada de 04 de outubro de 1465, em Guarda. Por falta da prévia citação, os vizinhos confinantes de um terreno dado em sesmaria, porém inculto, tinham dificuldades para a obtenção da água, perdendo muito tempo em demandas. Todavia, o problema poderia ser evitado se tivesse havido a citação dos vizinhos confinantes do terreno. Assim, os vizinhos do terreno a ser dado em sesmaria deveriam ser citados para se manifestar perante os juízes ordinários.

Por sua vez, a citação muitas vezes não era efetuada, porque os sesmeiros recebiam gratificações irrisórias de quem desejasse uma concessão de terras, como observa Gama Barros ${ }^{24}$ ao dizer que "por um casal de galinhas" era possível conseguir uma carta de qualquer terra. Certos "homens bons" não eram tão íntegros, como podemos inferir da leitura da lei.

Portanto, a execução da Lei de Sesmarias não proporcionou a efetiva produção agrícola almejada. Malgrado o teor coercitivo de sua letra, a sua aplicação ficou a cargo, em alguns casos, de pessoas arbitrárias, criando insegurança e insatisfação.

\footnotetext{
22 RAU, Virgínia. op. cit., p. 85

${ }^{23}$ BARROS, Henrique de Gama. op. cit. p. 334 e ss.

24 Id. Ibid., p. 346.
} 


\section{As sesmarias nas Ordenações Manuelinas e Filipinas}

O Reinado de D. Manuel foi marcado pela expansão marítima com o desenvolvimento do comércio. D. Manuel, em 09 de fevereiro de 1506, confia a missão de se elaborar uma compilação das leis do Reino, que, então, existiam muitas extravagantes e careciam de certa sistematização, a Ruy Boto, João Cotrim e, posteriormente, também integrariam a elaboração João de Faria, Pedro Jorge e Cristóvão Esteves. ${ }^{25}$ Em 1514, foi concluída a sua primeira impressão. Contudo, esta edição foi recolhida para ser corrigida, sendo proibido o seu uso. Finalmente, a edição definitiva veio a lume, em 1521.

Quanto à divisão, assim como as Afonsinas, segue-se a influência das Decretais de Gregório IX.

D. Filipe I, por seu turno, considerando o aumento de leis extravagantes, ordena a compilação da legislação a Jorge de Cabedo, Afonso Vaz Teneiro e Duarte Nunes de Leão, que já havia elaborado a compilação de leis extravagantes, aprovadas por D. Sebastião, no início de 1569. Entretanto, as Ordenações Filipinas somente começaram a viger no Reinado de D. Felipe II, em 11 de janeiro de 1603. Em geral, as Ordenações Filipinas não trouxeram inovações no seu sistema; a divisão dos livros segue as ordenações anteriores. $^{26}$

A sesmarias nas Ordenações Manuelinas são tratadas de forma mais concisa que nas Afonsinas. A redação tem estilo diverso, isto é, não se trata de uma compilação que apenas acrescenta uma lei em vigor "ipsis litteris", mas em estilo decretório, como salienta Mário Júlio de Almeida Costa. ${ }^{27}$

As Ordenações Filipinas, no que concerne às sesmarias, não alterou o instituto. Seguiu-se a redação das Ordenações Manuelinas, porém com algumas adaptações na disposição dos parágrafos, sem acréscimos consideráveis. Há, porém, um acréscimo procedente do "Código Sebastiânico", que permite às Igrejas, Ordens e pessoas eclesiásticas de "usar de qualquer título e prova" nas questões relacionadas à concessão de terras incultas (Ord. Filipinas, Livro IV, Título XLIII, n. 15, último parágrafo). ${ }^{28}$

Nas Ordenações Manuelinas a matéria se encontra no Livro IV, Título LXVII, ao passo que nas Filipinas a matéria é disciplinada no Livro IV, Título XLIV.

\footnotetext{
${ }_{25}$ AZEVEDO, Luiz Carlos de. Introdução à História do Direito. São Paulo: Editora Revista dos Tribunais, 2005. p. 208.

${ }^{26}$ COSTA, Mário Júlio de Almeida. op. cit., p. 290.

27 Id. Ibid., p. 284.

${ }^{28}$ Ordenações Filipinas. op. cit., p. 826.
} 
A definição de sesmarias, em ambos estatutos, encontra-se no preâmbulo, como segue:

SESMARIAS sam propriamente aquellas que se dam de terras, casas, ou pardieiros, que foram ou sam d'alguũs senhorios, e que já em outro tempo foram lauvradas $e$ aproueitadas, e agora o nom sam, as quaes terras, e os bens assi danificados $e$ destroidos, podem e deuem seer dados de Sesmarias polos Sesmeiros que pera esto forem ordenados, os quaes Sesmeiros a Nós soomente pertence de os dar, e poer nos Lugares onde ouuer terras, onde se as Sesmarias ouuerem de dar, forem foreiras ou tributarias a Nós, ou aa Coroa de Nossos Reynos, quer se os foros e tributos arrecadem pera Nós, quer pera outrem, a que os Tenhamos dados, Acustumamos dar por Sesmeiros os Nossos Almoxarifes dos Luguares, ou Almoxarifados onde, os taees bens, ou terras esteuerem. ${ }^{29}$

Sesmarias são propriamente as dadas de terras, casaes, ou pardieiros, que foram, ou são de alguns Senhorios, e que já em outro tempo foram lavradas e aproveitadas, e agora não o são.

As quaes terras, e os bens assi danificados, e destruidos podem e devem ser dados de sesmarias, pelos Sesmeiros, que para isto forem ordenados. E a Nós sómente pertence dar os ditos Sesmeiros, e os pôr nos lugares onde houver terras ou bens de raiz que de sesmaria se devão dar.

E se as terras onde se as sesmarias houverem de dar, forem foreiras, ou tributarias a Nós ou á Coroa de nossos Reynos, quer se os foros e tributos arrecadem para Nós, quer para outrem, a que os tenhamos dados, costumamos dar por Sesmeiros os nossos Almoxarifes dos lugares ou Almoxarifados, onde os taes bens ou terras estão". ${ }^{30}$

O preâmbulo das disposições sobre as sesmarias parece ter alterado o modo de escolha do sesmeiro, que antes era escolhido pelo concelho e confirmado pelo Rei, segundo Gama Barros. ${ }^{31}$ Da leitura do trecho acima, presumimos que a escolha cabia só ao Rei.

O acréscimo relevante às Ordenações Manuelinas e Filipinas foi a introdução de um procedimento para a distribuição de terras. Como vimos ao comentar a Lei de

\footnotetext{
${ }^{29}$ Ordenações Manuelinas. In: Collecção da Legislação Antiga e Moderna do Reino de Portugal - Parte I - Da Legislação Antiga - por resolução de S. Magestade de 02 de Setembro de 1786. Coimbra: Real Imprensa da Universidade de Coimbra, 1797; reprodução "fac-simile", Lisboa: Fundação Calouste Gulbenkian, 1984, p.164, negritos nossos.

${ }^{30}$ Ordenações Filipinas. op. cit. p. 822.

31 Vide nota de rodapé n. 13.
} 
Sesmarias, incorporada nas Ordenações Afonsinas, a falta de tal procedimento foi causa de muitos litígios e revoltas. Primeiramente, os sesmeiros deveriam citar o proprietário da terra passiva de ser dada em sesmarias. Depois da citação, deveria ser aberta audiência para ouvir o senhorio e os requerentes da concessão de sesmarias. Não comparecendo à audiência, no prazo de um ano, o senhorio deveria tornar a terra culta. No desconhecimento do senhorio das terras, o sesmeiro devia publicar editais onde se encontravam as terras, bem como nas proximidades. No edital deveria conter: a localização do imóvel, as confrontações do imóvel, o nome do proprietário e o prazo de um ano para "lavrar e aproveitar". Passado um ano, a contar do trigésimo dia da publicação dos editais. (Ord. Manuelinas, Livro IV, Título LXVII, ns. 1 e 2; Ord. Filipinas, Livro IV, Título XLIII, n. 1 e 2).

Havia um prazo para a concessão das datas de sesmarias de no máximo cinco anos, sob pena de multa, se não fossem aproveitadas (Ord. Manuelinas, Livro IV, Título LXVII, n. 3; Ord. Filipinas, Livro IV, Título XLIII, n.3). Na consulta do sesmeiro d'Estremoz, observamos que ele relata a D. Duarte sobre terras improdutivas há décadas (Ord. Afonsinas, Livro IV, Título LXXXI, n. 26). Por conseguinte, a fixação de prazo para tornar a terra produtiva reforça a idéia de efetivo plantio ou uso para pastagem.

Os termos das Ordenações Afonsinas em relação às Manuelinas e Filipinas são mais flexíveis. Não há o verbo constranger em todo o texto. Por sua vez, na Lei de Sesmarias encontramos o emprego constante do verbo aproveitar em acréscimo ao verbo lavrar, que enseja a extensão da lei para a pecuária, embora ainda dependente do plantio, ou liberdade para o concessionário executar outras atividades. Logo, não era permitida a concessão de sesmarias somente para a criação de gado.

As Ordenações Manuelinas e as Filipinas repetem algumas disposições da Lei de Sesmarias, porém, em outros termos, como demonstra o exemplo abaixo:

8. E por quanto algumas pessoas deixam perder seus olivaes, e colher mato, poros não quererem adubar, nem roçar, e para lhos não pedirem de sesmaria, escavam, ou cultivam algumas oliveiras, e não querem roçar os matos. E outros, que tem terras para dar pão, as deixam encher de grandes matos e soveraes, e por lhos não pedirem, lavram hum pedaço de terra, e deixam toda a outra. E alguns deixam perder as vinhas, e tornar em pousios, e adubam humas poucas de cepas em hum cabo e outras em outro, $e$ allegam, que as aproveitam.

Mandamos que os donos dos taes bens sejam requeridos, e lhes seja assinado termo, a que adubem os ditos olivaes e vinhas, e as terras lavrem, e semêem ás folhas, segundo 
o costume da terra. E se o assi não fizerem, passado o dito termo, as dêm de sesmaria. ${ }^{32}$

Do confronto entre o texto das Ordenações Afonsinas e das Ordenações Manuelinas e Filipinas, observamos que o trecho cogente ao final das Ordenações Manuelinas e Filipinas é mais elaborado e preciso, enquanto que nas Ordenações Afonsinas é mais impreciso, não determinando como usar a terra, nem fixando um prazo para a observação da ordenação. Portanto, vemos um avanço na técnica legislativa, assim como no sentido de atenuar os poderes dos sesmeiros.

Embora não abordamos a aplicação das sesmarias no Brasil, as sesmarias foram revogadas pela Lei n. 601, de 13 janeiro de 1850, onde se encontra a definição de terras devolutas. Salienta-se que essa lei é vigente no que atine a definição de terras devolutas.

Cândido Mendes de Almeida, ${ }^{33}$ em notas de rodapé ao Título XLIII das Ordenações Filipinas, enfatiza que as sesmarias no Brasil tomaram novos moldes, por meio de legislação especial para o ultramar e aplicação diversa da metrópole.

\section{Conclusão}

As sesmarias foram um grande passo legislativo em prol da agricultura. Nãoobstante, a ênfase inicial fosse quase totalmente focada no plantio de gêneros alimentícios para suprir a onda de fome no final do século XIV, as sesmarias foram transplantadas para o corpo das três Ordenações do reino, sublinhando sempre a necessidade da agricultura.

No entanto, não vislumbramos o efetivo uso da terra destinado ao plantio de gêneros alimentícios, pois as disposições das sesmarias nas três Ordenações tratam da distribuição de terras e dos modos coercitivos de tornar a terra produtiva, embora há evidências de aplicação da lei na consulta do sesmeiro Álvaro Gonçalo. Este demonstrou que a lei não conseguiu a produção almejada por desinteresse dos concessionários ou por má fiscalização.

Em geral, em alguns pontos as Ordenações Manuelinas repetiram as disposições das Ordenações Afonsinas, sem grandes inovações, o que não deixa de ser um melhoramento na disciplina do instituto. O procedimento introduzido nas Ordenações Manuelinas tornou mais preciso o modo de distribuir e usar a terra ao fixar prazos certos, não deixando ao total arbítrio do sesmeiro.

\footnotetext{
${ }^{32}$ Ordenações Filipinas. op. cit. , p. 824 e 825.

${ }^{33}$ Id. Ibid., notas de rodapé da p. 822.
} 
Nas duas últimas Ordenações do Reino, a ênfase do texto legal é a distribuição de terras em relação ao texto das Ordenações Afonsinas, que incorporou a Lei de D. Fernando, ressaltando esta a importância da agricultura voltada para a alimentação.

Podemos dizer que as sesmarias foram o marco inicial no ordenamento jurídico luso-brasileiro de normas de cunho agrário. O seu cerne ainda permanece no nosso ordenamento, ressaltando a função social da propriedade imobiliária rural, uma vez que a efetiva produção de gêneros alimentícios e a distribuição equânime da terra são o norte da nossa política agrária (Capítulo III, Título VIII, da Constituição Federal, de 1988; $\S 1^{\circ}$, art. $2^{\circ}$, Lei n. 4.504, de 30 de novembro de 1964 - Estatuto da Terra.). Por outro lado, a Lei de D. Fernando, há mais de 600 anos, tem presente no seu âmago uma necessidade existencial do ser humano, embora hoje seja chamada de segurança alimentar e definida na recente Lei n. 11.346, de 15 de setembro de 2006: a garantia de existir sempre alimentos suficientes para saciar a fome de todos os cidadãos.

São Paulo, setembro de 2007.

\section{Referências}

AZEVEDO, Luiz Carlos de. Introdução à História do Direito. São Paulo: Editora Revista dos Tribunais, 2005.

BARROS, Henrique de Gama. História da Administração Pública em Portugal nos séculos XII a $X V$. Direção de Torquato de Souza Soares. 2. ed. Lisboa: Sá da Costa, 1945. v. 8.

CAETANO, Marcelo. História do Direito Português (séculos XII a XVI) seguida de subsídios para a História das Fontes do Direito em Portugal no século XVI. Introdução e notas de Nuno Espinosa Gomes da Silva. Lisboa: Editora Verbo, 2000.

COSTA, Mário Júlio de Almeida. História do Direito português. 3. ed. 2. reimp. Coimbra: Almedina, 2000 .

HERCUlANO, Alexandre. História de Portugal, desde o começo da monarquia até o fim do Reinado de D. Afonso III. Lisboa: Livraria Bertrand, 1980. t. 2.

HOUAISS, Antônio. Dicionário Eletrônico Houaiss da Língua Portuguesa. Rio de Janeiro: Editora Objetiva Ltda., 2002.

RAU, Virgínia. Sesmarias Medievais Portuguesas. Lisboa: Editorial Presença, 1982. 
ROCHA, Olavo Acyr de Lima. As Ordenações Filipinas e o Direito Agrário. Revista da Faculdade de Direito da Universidade de São Paulo, São Paulo, v. 95, p. 33-55, jan./ dez. 2000. (Edição em homenagem aos 500 anos do Descobrimento do Brasil).

Legislação

ORDENAÇÕES Afonsinas. In: Collecção da Legislação Antiga e Moderna do Reino de Portugal - Parte I - Da Legislação Antiga - por resolução de S. Magestade de 02 de Setembro de 1786, Coimbra: Real Imprensa da Universidade de Coimbra, 1797; reprodução "fac-simile", Lisboa: Fundação Calouste Gulbenkian, 1984.

ORDENAÇÕES Filipinas. Lisboa: Fundação Calouste Gulbenkian, 1985; reprodução fac-símile da edição brasileira de Cândido Mendes de Almeida, 14. ed. Rio de Janeiro: Tipografia do Instituto Filomático, 1870. Edição segundo a primeira de 1603 e a nona de 1824.

ORDENAÇÕES Manuelinas. In: Collecção da Legislação Antiga e Moderna do Reino de Portugal - Parte I - Da Legislação Antiga - por resolução de S. Magestade de 02 de Setembro de 1786. Coimbra: Real Imprensa da Universidade de Coimbra, 1797; reprodução "fac-simile", Lisboa, Fundação Calouste Gulbenkian, 1984. 